\title{
KONSEP PASAR MODAL SYARIAH
}

\author{
Oleh : Nabila Rajab \\ Jurusan Perbankan Syariah Fakultas Ekonomi Dan Bisnis Islam \\ Universitas Islam Negeri Alauddin Makassar
}

Email : nabilarajab30@gmail.com

\begin{abstract}
:
Economic development of a country cannot be separated from the capita lmarket. Capital market serves as a means to mobilize public funds and to search the own ership of shares of a company by sellingit. Islamic capital market serves as an investment medium for Muslims in the capital market that is in line with Islamic principles. Some criteria for the establishment of the islamic capital market are form ingpricefairly, the presence of perfec tinformation, free from riba, gharar, gambling and other transactions that contradict against sharia rules. Stocks traded in the islamic capital market should come from issuers that meet the Islamic criteria and bonds issued should use mudarabah, musharaka, ijara, istisna'and salam.
\end{abstract}

Keywords: Islamic capital market, criteria of the Islamic capital market, contracts at the islamic

capitalmarket.

\section{Pendahuluan}

Definisi pasar modal sesuai dengan Undang-undang Nomor 8 Tahun 1995 tentang Pasar Modal (UUPM) adalah kegiatan yang bersangkutan dengan Penawaran Umum dan perdagangan Efek, Perusahaan Publik yang berkaitan dengan Efek yang diterbitkannya, serta lembaga dan profesi yang berkaitan dengan Efek. Berdasarkan definisi tersebut, terminologi pasar modal syariah dapat diartikan sebagai kegiatan dalam pasar modal sebagaimana yang diatur dalam UUPM yang tidak bertentangan dengan prinsip syariah. Oleh karena itu, pasar modal syariah bukanlah suatu sistem yang terpisah dari sistem pasar modal secara keseluruhan. Secara umum kegiatan Pasar Modal Syariah tidak memiliki perbedaan dengan pasar modal konvensional, namun terdapat beberapa karakteristik khusus Pasar Modal Syariah yaitu bahwa produk dan mekanisme transaksi tidak bertentangan dengan prinsipprinsip syariah. Penerapan prinsip syariah di pasar modal tentunya bersumberkan pada Al Quran sebagai sumber hukum tertinggi dan Hadits Nabi Muhammad SAW. Selanjutnya, dari kedua sumber hukum tersebut para ulama melakukan penafsiran yang kemudian disebut ilmu fiqih. Salah satu pembahasan dalam ilmu fiqih adalah pembahasan tentang muamalah, yaitu hubungan diantara sesama manusia terkait perniagaan. Berdasarkan itulah kegiatan pasar modal syariah dikembangkan dengan basis fiqih muamalah. Terdapat kaidah fiqih muamalah yang menyatakan bahwa "Pada dasarnya, semua bentuk muamalah boleh dilakukan kecuali 
ada dalil yang mengharamkannya." Konsep inilah yang menjadi prinsip pasar modal syariah di Indonesia (Ali, 2016).

\section{Pembahasan}

\section{Sejarah Pasar Modal}

Perkembangan pasar modal konvensional di Indonesia sudah dimulai sejak tahun 1912. Efek yang Diperdagangkan pada masa itu adalah saham dan obligasi perusahaanperusahaan Belanda dan

Pemerintah Hindia Belanda. Akan tetapi, aktifitas pasar modal tersebut berhenti ketika terjadi perang Dunia kedua. Kegiatan bursa efek dibuka kembali setelah Indonesia memperoleh kemerdekaan dengan Diterbitkannya obligasi pemerintah Indonesia tahun 1950. Pengaktifan ini didukung dengan UU Darurat Tentang Bursa No. 13 tahun 51 yang kemudian ditetapkan dengan UU No. 15 tahun 52 (Usman, 1990: 185-189).Pasar modal syariah dibuka secara resmi pada tanggal 14 Maret 2003 oleh Menkeu Boediono yang Didampingi oleh ketua Bapepam Herwidayatmo, wakil dari MUI, wakil DSN dari direksi SRO, direks Perusahaan efek, pengurus organsasi pelaku dan asosiasi profesi di pasar modal Indonesia. Sebenarnya,Sesuai rencana pasar modal syariah diresmikan pada awal Nopember 2002. Akan tetapi, pada saat itu Bapepem dan Dewan Syariah Nasional belum merasa siap. Hal ini berkaitan dengan banyaknya kendala Yang belum selesai dibahas (Usman, 1990: 185). Sebelumnya, Bapepam telah mengkaji cukup lama dan Bahkan telah mengirim delegasi untuk studi banding dan melihat mekanisme beroperasinya pasar modal Syariah di berbagai pasar modal syariah dunia (Sholahuddin, 2006): 155).

Hadirnya pasar modal syariah diharapkan menjadi tonggak sejarah baru, seperti Bank Muamalat Indonesia (BMI) yang dibuka pada satu dasawarsa yang lalu (Sholahuddin, 2006: 155). Aktifitas di Pasar modal syariah memang belum lama diperkenalkan. Sebelum kehadirannya, telah muncul Reksadana syariah pada tahun 1997 yang kemudian diikuti oleh peluncuran Jakarta Islamic Index (JII) Pada tahun 2000. Menkeu Boediono sendiri mengharapkan, dengan muculnya pasar modal syariah ini Seyogyanya diikuti oleh hasil karya kongkrit dan pengembangan instrumen-instrumen lain yang berbasis Syariah, sebagai mana negara-negara maju telah merintis pengembangan instrumen syariah di pasar Modal dengan munculnya Dow Jones Islamic Index (DJII).

\section{Pengertian Pasar Modal Syariah}

Pasar modal(capitalmarket) merupakan bagian dari institusi-institusi keuangan (financialInstitutions).6 Hugh T. Patrick \& U Tun Wai menyebutkan 3 (tiga) definisi pasar modal; Pertama, dalam arti luas, pasar modal adalah keseluruhan sistem keuangan yang terorganisir, Termasuk bank-bank komersil dan semua perantara di bidang keuangan, surat berharga/klaim Jangka pendek panjang primer yang tidak langsung. Kedua, dalam arti menengah, pasar modal Adalah semua pasar yang terorganisir dan lembaga-lembaga yang memperdagangkan warkat-Warkat kredit (biasanya yang berjangka lebih dari 1 tahun) termasuk saham, obligasi, pinjaman Berjangka, hipotek tabungan dan deposito berjangka. Ketiga, dalam arti sempit, pasar modal Adalah tempat pasar teorganisir yang memperdagangkan saham dan obligasi dengan Menggunakan jasa makelar dan 
underwriter.Jika ditinjau menurut pengertian lain disebutkan Bahwa pasar modal adalah thestockexchangeandotherinstitutionswheresecurities are boughtAndsold.Sejalan dengan pengertian ini, Dahlan Siamat juga menjelaskan bahwa pasar modal Adalah suatu tempat yang terorganisasi di mana efek-efek diperdagangkan yang disebut Bursa Efek.Secara lebih teknis, di dalam Undang-Undang No. 8 Tahun 1995 tentang Pasar Modal Disebutkan bahwa Pasar Modal adalah kegiatan yang bersangkutan dengan Penawaran Umum Dan perdagangan efek, perusahaan publik yang berkaitan dengan efek yang diterbitkannya,Serta lembaga dan profesi yang berkaitan dengan efek.Definisi-definisi di atas dapat disimpulkan bahwa pasar modal merupakan salah satu bentuk Kegiatan dari lembaga keuangan non bank sebagai sarana untuk memperluas sumber-sumber Pembiayaan perusahaan. Aktivitas ini terutama ditujukan bagi perusahaan yangmembutuhkan Dana dalam jumlah besar dan penggunaannya diperlukan untuk jangka panjang(long term) (Muhammad Yafidz, n.d.).

\section{Hukum Pasar Modal}

Tidak dijumpai baik dalam Al-Qur'an maupun Hadist nash yang membicarakan tentang masalah pasar Modal dan juga hukumnya. Namun demikian, perdagangan saham tidak bertentangan dengan hukum Islam. Akan tetapi, kebolehan jual beli saham ini terbatas pada saham-saham yang bidang usahanya Tidak bertentangan dengan ketentuan-ketentuan syariat Islam. Seperti, perusahaan-perusahaan yang Memproduksi makanan, minuman atau jasa yang tidak dilarang Agama (Lubis, 2004: 91). Oleh karena Itu, orang Islam yang ingin membeli saham suatu perusahaan, terlebih dahulu harus mengadakan Penyelidikan yang saksama tentang bidang usaha dari perusahaan yang menawarkan saham tersebut. Dewan Syariah Nasional (DSN) Majelis Ulama Indonesia (MUI) pada tahun 2003 mengeluarkan fatwa tentang kebolehan bertransaksi di pasar modal selama mekanisme dan objeknya tidak bertentangan dengan prinisp syariah. Fatwa yang dikeluarkan oleh DSN berkaitan dengan ketentuan umum pasar modal syariah, prinsip-prinsipnya, emiten yang menerbitkan efek syariah, kriteria dan jenis efek syariah, transaksi yang dilarang dan penentuan harga saham (DSN-MUI, 2006: 264-277).

Kemunculan fatwa DSN-MUI di atas dilatarbelakangi oleh beberapa hal sebagai berikut (DDSN MUI, 2006: 264): a) Perkembangan ekonomi suatu negara tidak mungkin lepas dari perkembangan pasar modal; b) Beberapa negara telah mengembangkan pasar modal syariah; c) Umat Islam Indonesiamemerlukan pasar modal yang aktivitasnya sejalan dengan prinsip syariah.Di bawah ini akan dipaparkan tentang fatwa DSN yang berkaitan dengan mekanisme transaksi dipasar modal syariah. Fatwa ini terdapat pada bab $\mathrm{V}$ tentang Transaksi Efek dan Pasal 5 yang berkaitan dengan Transaksi yang dilarang, sebagai berikut (DSN-MUI, 2006: 276-277):

1. Pelaksanaan transaksi harus dilakukan menurut prinsip kehati-hatian serta tidak boleh melakukan spekulasi dan manipulasi yang di dalamnya mengandung unsur dharar,gharar, riba, maisir, risywah, maksiat dan kezaliman.

2. Tindakan spekulasi transaksi yang mengandung unsur dharar, gharar, riba, maisir, risywah, maksiat dan kezaliman sebagaimana di maksud dalam ayat 1 di atas meliputi:

a) Najsy, yaitu melakukan penawaran palsu; b) Bai' al-a'dum, yaitu melakukan penjualan atas barang (efek syariah) yang belum dimiliki (shortselling); c) Insidertrading, yaitu 
memakai informasi orang dalam untuk memperoleh keuntungan atas transaksi yang dilarang; d) Menimbulkan informasi yang menyesatkan;e) Medilarang investasi pada emiten (perusahaan) yang pada saat transaksi tingkat (nisbah) utang perusahaan kepada lembaga keuangan ribawi lebih dominan dari modalnya; f) Margin trading, yaitu melakukan transaksi atas efek syariah dengan fasilitas pinjaman berbasis bunga atas kewajiban penyelesaian pembelian efek syariah tersebut; g) Ikhtikar (penimbunan), yaitu melakukan pembelian atau dan pengumpulan suatu efek syariah untuk menyebabkan perubahan harga efek syariah, dengan tujuan mempengaruhi pihak lain; h) Dan transaksi-transaksi lain yang mengandung unsur di atas.

\section{Fungsi Pasar Modal Syariah}

Menurut M. Metwally sebagaimana dikemukakan oleh Heri Sudarsono, menyebutkan ada lima fungsi Dari pasar modal syariah. Kelima fungsi pasar modal syariah tersebut adalah sebagai berikut (Sudarsono2007: 186):

a. Memungkinkan bagi masyarakat berpartisipasi dalam kegiatan bisnis dengan memperoleh bagian Dari keuntungan dan resikonya.

b. Memungkinkan para pemegang saham menjual sahamnya guna mendapatkan likuiditas.

c. meganghaan untuk meningkatkan modal dari luar untuk membangun dan mengembangkan lini produksinya.

d. Memisahkan operasi kegiatan bisnis dari fluktuasi jangka pendek pada harga saham yang merupakan ciri umum pasar modal konvensional.

e. Memungkinkan investasi pada ekonomi itu ditentukan oleh kinerja kegiatan bisnis sebagaimana tercermin pada harga saham.

f. Dari beberapa fungsi pasar modal syariah di atas diketahui bahwa keberadaan pasar modal syariah sangat bermanfaat dalam rangka meningkatkan aktifitas perekonomian umat Islam dan selanjutnya dapat meningkatkan kesejahteraan mereka.

\section{Peran dan Manfaat Pasar Modal}

Peran bursa efek sebagai berikut.

1. Menyediakan semua sarana perdagangan efek (fasilitator).

2. Membuat peraturan yang berkaitan dengan kegiatan bursa.

3. Mengupayakan likuiditas instrumen.

4. Mencegah praktik yang dilarang di bursa (kolusi, pembentukan harga yang tidak wajar, insidertrading, dan sebagainya).

5. Menyebarluaskan informasi bursa.

6. Menciptakan instrumen dan jasa baru. 
Manfaat keberadaan pasar modal sebagai berikut.

1. Menyediakan sumber pembiayaan (jangka panjang) bagi dunia usaha sekaligus memungkinkan alokasi sumber dana secara optimal.

2. Memberikan wahana investasi bagi investor sekaligus memungkinkan upaya diversifikasi.

3. Menyediakan leadingindicator bagi trend ekonomi negara.

4. Penyebaran kepemilikan perusahaan sampai lapisan masyarakat menengah.

5. Penyebaran kepemilikan, keterbukaan dan profesionalisme, menciptakan iklim berusaha yang sehat.

6. Menciptakan lapangan kerja/profesi yang menarik.

7. Memberikan kesempatan memiliki perusahaan yang sehat dan mempunyai prospek.

8. Alternatif investasi yang memberikan yang memberikan potensi keuntungan dengan risiko yang dapat diperhitungkan melalui keterbukaan, likuiditas, dan diversifikasi investasi.

9. Membina iklim keterbukaan bagi dunia usaha, memberikan akses kontrol sosial.

10. Pengelolaan perusahaan dengan iklim keterbukaan, mendorong pemanfaatan manajemen professional.

11. Sumber pembiayaan dana jangka panjang bagi emiten.

Instrumen-instrumen pasar modal yang sesuai dengan syari'ah adalah (Zahroh, 2015):

1. Muqaradah/MudharabahFunds

Dana mudharabah ini berbentuk saham yang memberikan Kesempatan kepada investor untuk bersama-sama dalam pembiayaan Atau investasi dengan perjanjian bagi hasil dan bagi risiko (profit lossSharing). Pihak-pihak yang bergabung dalam investasi ini biasanya diikat Dengan perjanjian syirkah (musyarakah) bila badan usaha tersebut Berbentuk Perseroan Terbatas (pemilik dana dapat ikut serta secara Langsung dalam pengelolaan usaha). Dan bila kemudian hari ada pihak Lain yang ingin bergabung, maka ia dapat mengambil alih (sebagian) Saham yang dimiliki oleh pemegang saha sebelumnya atau membeli Saham baru yang diterbitkan oleh perusahaan tersebut. MudharabahFund ini harus diinvestasikan sesuai syari'ah.

\section{Saham Biasa (CommonStock)}

Saham biasa perusahaan yang tidak melakukan transaksi yang Haram diperbolehkan oleh syari'ah dalam perdagangan dipasar modal Karena dinilai sesuai dengan prinsip keadilan, dimana proporsi Keuntungan dan kerugian dibagi sama.

3. Muqaradah/MudharabahBonds (Obligasi Muqaradah/Mudharabah)

Jenis obligasi ini dikeluarkan oleh perusahaan untuk tujuan Pembiayaan pada proyek-proyek tertentu atau proyek yang terpisah dari Kegiatan perusahaan yang bersifat jangka panjang. Sistem yang Dijalankan MuqaradahBonds hampir sama dengan Mudharabah yaitu Dengan profit-losssharing. 


\section{Jenis-Jenis Pasar Modal}

menjalankan fungsinya, pasar modal dibagi menjadi tiga macam. Yaitu, pasar primer, pasar Sekunder dan bursa parallel (Rivai dkk, 2007: 935):

\section{a) Pasar Perdana (PrimaryMarket)}

Pasar perdana merupakan pasar di mana emiten pertama kali memperdagangkan saham atau Surat berharga lainnya. Kegiatan ini biasa dinamakan dengan penawaran umum atau InitialPublicOffering (IPO). Informasi suatu perusahaan yang akan menawarkan sahamnya untuk pertama kali pada Masyarakat, dapat dilihat minimal di dua harian nasional, publik ekspose atau prospektus. Prosedur Pembeliannya melalui pengisian Formulir Pemesanan Pembelian Saham (FPPS) yang tersebar melalui Underwriter atau penjamin emisi efek atau agen-agen penjual lainnya yang ditunjuk (Rivai dkk, 2007: 935). Harga saham pada pasar perdana merupakan harga pasti yang tidak dapat ditawar lagi. Harga ini Ditetapkan oleh perusahaan penjamin emisi dan emiten (Haroen, 2000: 53).

\section{Pasar Sekunder (SecondaryMarket)}

Pasar sekunder adalah pasar yang memperdagangkan efek setelah penawaran di pasar perdana. Perdagangan di pasar sekunder hanya terjadi antar investor yang satu dengan lainnya. Transaksinya Tidak lepas dari bursa saham sebagai fasilitator perdagangan di pasar modal. Pembelian di pasar ini, Hanya pada saham yang telah beredar berdasarkan aturan main yang telah ditetapkan pasar. Prosedurnya, Investor melakukan order beli atau jual melalui broker dan kemudian ia menerukannya ke pasar atau Bursa (Rivai dkk, 2007: 935).Harga saham di pasar sekunder tidak lagi ditentukan oleh emiten dan penjamin emisi, tetapi Berdasarkan atas teori penawaran dan permintaan serta prospek perusahaan yang menerbitkan saham.Dengan demikian, harga saham di pasar sekunder dapat lebih tinggi dari pasar perdana (Haroen, 2000: 82).

b) Bursa Paralel

Tidak semua efek yang diterbitkan dapat dijual di bursa efek, karena persyaratan untuk Mendaftar di bursa efek sangat ketat. Bursa paralel merupakan alternatif bagi perusahaan yang gopublic Yang tidak dapat memenuhi syarat yang ditentukan bursa efek. Emiten-emiten yang mendaftarkan Efeknya di bursa paralel, modalnya relatif lebih kecil. Atas dasar ini, bursa paralel merupakan pelengkap Bagi pasar bursa efek yang sudah ada (Rivai dkk, 2007: 934-935).

\section{Mekanisme Beroperasinya Pasar Modal Syariah}

Transaksi di pasar modal, investor dapat langsung meneliti dan menganalisa keuntunganMasing-masing perusahaan yang menawarkan modal. Apabila investor mengetahui adanya kemungkinan Mendapatkan keuntungan dari jual beli saham, ia dapat langsung membeli saham tersebut dan Menjualnya kembali ketika harganya naik pada pasar yang sama. Jadi, investor dapat pula menjadi Penjual saham kepada investor yang lain (Kasmir, 2004: 194).Pasar modal syariah sejatinya harus bebas dari transaksi-transaksi yang tidak beretika dan Bermoral, seperti insidertrading dan shrotselling. Menurut al-Habsyi yang dikemukakan oleh Sholahuddin, idealnya pasar modal syariah tidak mengandung transaksi 
ribawi, gharar dan saham Perusahaan yang bergerak pada jenis usaha yang tidak dilarang syariah (Sholahuddin, 2006: 164-165).Sementara itu Obeidillah yang yang juga dikutip oleh Sholahuddin, mengemukakan beberapa etika Di pasar modal. Menurutnya, pasar modal syariah harus mencakup kriteria-kriteria di bawah ini(Sholahuddin, 2006: 165): a) Setiap orang bebas melakukan transaksi (freedomcontrac) selama tidak.Bertentangan dengan syariah; b) Bentuk transaksi harus bersih dari unsur riba, gharar dan judi; c) Harga Terbentuk secara fair; d) Terdapat informasi yang sempurna.

Oleh karena itu, pasar modal syariah harus membuang jauh-jauh setiap transaksi yang Mengandung unsur spekulasi. Hal inilah yang membedakannya dengan pasar modal konvensional yang Salah satu cara untuk mendapat keuntungannya dengan menggunakan spekulasi. Walaupun diakui, Dalam kasus-kasus tertentu seperti insidertrading dan manipulasi pasar dengan membuat laporan yangPalsu dilarang pada pasar modal konvensional (Sholahuddin, 2006: 165).Dalam mekanisme transaksi produk di pasar modal syariah, Irfan Syuqi mengemukakan wacana Pembelian dan penjualan saham tidak boleh dilakukan secara langsung. Dalam pasar modal Konvensional, investor dapat membeli atau menjual saham secara langsung dengan menggunakan jasa Broker atau pialang. Keadaan ini memungkinkan bagi para spekulan untuk memainkan harga saham. Dampaknya, perubahan harga saham ditentukan oleh kekuatan pasar bukan oleh nilai intrinsiknya. Untuk itu, dalam pasar modal syariah, emiten memberikan otoritas kepada agen di lantai bursa. Selanjutnya, agen tersebut bertugas untuk mempertemukan emiten dengan calon investor, tetepi bukan Untuk kenjual dan membeli saham secara langsung. Kemudian, saham tersebut dijual atau dibeli karana Sahamnya memang tersedia berdasarkan firstcome-firsserved.Dalam perdagangan obligasi syariah, menurut Muhammad Gunawan, tidak boleh diterapkan harga Diskon atau harga premium yang lazimnya dilakukan pada obligasi konvensional. Prinsip transaksi Obligasi syariah adalah al-hiwalah, yaitu transverservice atau pengalihan piutang dengan tanggungan Bagi hasil. Oleh karena itu, jual beli obligasi syariah hanya boleh pada harga nominal pelunasan jatuh Tempo obligasi (Sholahuddin, 2006: 165).Sedangkan dalam perdagangan reksa dana syariah, manajer investasi menawarkan kepada pembeli Reksa dana syariah baik yang bersifat jangka panjang atau jangka pendek. Reksa dana syariah jangka Panjang ditawarkan di pasar saham dan reksa dana syariah di tawarkan di pasar uang. KeuntunganInvestor dari reksa dana syariah tergantung bagaimana manajer investasi menginvestasikan dana yangDikelolanya (Sholahuddin, 2006: 165).

\section{Karakteristik Pasar Modal Syariah}

Menurut Mokhtar Muhammad Metwally (Rifai, 2009) karakteristik pasar modal Syariah adalah:

1. Semua saham harus diperjual belikan pada bursa efek.

2. Bursa perlu mempersiapkan pasca perdagangan dimana saham dapat Diperjualbelikan melalui pialang.

3. Semua perusahaan yang mempunyai saham yang dapat diperjualbelikan di bursa

Efek diminta menyampaikan informasi tentang perhitungan (account) kentungan Dan kerugian serta neraca keuntungan kepada komite manajemen bursa efek,Dengan jarak tidak lebih dari tiga bulan sekali. 
4. Komite manajemen menerapkan harga saham tertinggi (HST) tiap tiap perusahaan Dengan interval tidak lebih dari tiga bulan sekali.

5. Saham tidak boleh diperjual belikan dengan harga lebih tinggi dari HST .

6. Saham dapat dijual dengan harga dibawah HST.

7. Komite manajemen harus memastikan bahwa semua perusahaan yang terlibatDalam bursa efek itu mengikuti standarakuntansi syariah.

8. Perdagangan saham mestinya hanya berlangsung dalam satu minggu priodePerdagangan setelah menentukan HST

9. Perusahaan hanya dapat menerbitkan saham baru dalam periode perdaganganDengan harga HST.(Awaluddim, 2016 : 139-140)

Menentukan Harga Saham

Ada dua pendekatan yang dapat digunakan untuk menghitung harga saham suatu perusahaan. Kedua pendekatan tersebut adalah (Huda dan Nasution, 2007: 175-176):

a. Pendekatan devidenDeviden merupakan sebagian dari keuntungan yang dibagikan kepada para pemegang saham. Bagi investor, jumlah rupiah yang diterima dari pembayaran deviden resikonya lebih kecil dari capital gain. Deviden adalah pendapatan yang dapat diperkirakan sebelumnya, sedangkan capital gain sulit diperkirakan. Harga saham dapat diketahui dengan menghitung nilai sekarang (presentvalue) dari proyeksi deviden yang akan diterima investor.Pembayaran deviden yang tinggi akan menimbulkan adanya anggapan bahwa perusahaan emiten Mempunyai prospek keuntungan yang baik. Demikian pula sebaliknya, penurunan pembayaran deviden Dianggap sebagai penurunan tingkat keuntungannya. Naik turunnya harga saham kemudian cenderung Ditentukan naik turunnya besarnya deviden yang dibayarkan.

\section{b. Pendekatan PriceEarningRatio (PER)}

PER adalah ratio antara harga berbanding proyeksi keuntuangnpersaham. PER menggambarkan Kesediaan investor membayar suatu jumlah untuk setiap rupiah perolehan laba perusahaan. PER sering Digunakan oleh para analis sekuritas untuk menialai harga saham dan penjamin emisi efek guna Menentukan harga saham di pasar perdana dengan cara mengalikan PER industri sejenis yang berlaku di Pasar sekunder dengan proyeksi laba bersih pertahun.Di sisi lain, keputusan kapan saham dijual dan dibeli ditentukan oleh perbandingan antara Nilainya dengan harga pasarnya (Huda dan Nasution, 2007: 176): a) Jika harga saham lebih kecil dari Nilainya, maka saham tersebut harus dibeli dan ditahan (buyandhold) dengan tujuan untuk memperoleh Capital gain pada saat harga mengalami kanaikan kembali di kemudian hari; b) Jika harga saham sama Dengan nilainya, maka saham tersebut dalam kondisi keseimbangan. Apabila bila harga saham lebih Besar dari nilainya, makaa saham tersebut harus dijual untuk menghindari kerugian. Karena, harganya di Kemudian hari akan turun menyesuaikan dengan nilainilai

c) Dalam kondisi di mana Internal Rate ofReturn (IRR) lebih besar dari costofcapital, maka nilai saham akan maksimal karena ada sebagian laba Ditahan yang kemudian diinvestasikan kembali. Dengan demikian, terdapat peluang untuk mendapatkan Deviden yang lebih besar di masa yang akan datang; 
d) Apabila dalam kondisi declingfirm, maka Penginvestasian kembali pada tahun pertama akan menurunkan nilai saham. Saham perusahaan yang Sedang merosot sangat riskan untuk dimiliki dengan strategi buyandhold;

e) Jika tingkat imbalan hasil Yang diharapkan menjadi pertimbangan utama investor, maka ia harus menetapkan terlebih dahulu hasil Yang diharapkan. Kemudian, ia baru menghitung pada harga berapa saham tersebut layak dibeli;

f) Apabila harga saham menjadi pertimbangan utama, maka investor harus berangkat dari harga yang layak Dibeli. Kemudian, ia menghitung tingkatan imbalan hasil yang diharapkan.Ketentuan-ketentuan di atas tentang kapan suatu saham harus dibeli atau dijual, kelihatannya Mudah diapahami namun sulit diterapkan. Kesulitannya adalah terletak pada menentukan nilai saham Yang bersangkutan. Di hari-hari crash, beta (resiko) mengalami peningkatan tanpa dibarengi dengan harapan Keuntungan yang proporsional. Dalam hal ini terdapat beberapa faktor eskternal yang bersifat khusus yang mempengaruhi terhadap perkembangan harga saham. Faktor-faktor ekternal tersebut antara lain

adalah: a) Kebijakan pemerintah untuk menaikkan atau menurunkan suku bunga SBI; b) Naik turunnya suku bunga overright; c) Pergerakan mata uang Rupiah atau Dollar Amerika Serikat; d) Bertiupnya sentimen-sentimen negatif yang mempengaruhi pasar; e) Rasionalitas investor dalam menghubungkan kinerja fundamental perusahaan emiten dengan expectedreturn dari pembelian sahamnya.

Perbedaan antara Investor dan Spekulan

MenurutNafik (2009:75) praktik di lapangan menunjukkan bahwa sangat Sulit membedakan antara tindakan investasi dan spekulasi karena keduanya sama-Sama bertujuan untuk mendapatkan pengembalian lebih terhadap apa yang mereka Lakukan, utamanya sebagai pelaku di pasar modal. Meskipun sulit untuk Dibedakan, terdapat perbandingan yang tampak berbeda antara investor dan Spekulan seperti pada tabel berikut ini (1369, مكردجيان):

Investor dan Spekulan

A.Investor

a. dalam mengambil keputusan

b.Berhati-hati dan melakukan analisis dengan cermat

c. Mengumpulkan informasi selengkap mungkin

d.Mengharapkan pengembalian pada jangka relatif panjang

e.Pada umumnya resiko yang diambil bersifat moderat

f.Mengharapkan pengembalian yang sesuai dengan resiko

g.Menginginkan harga sekuritas sebagai cerminan informasi dan kondisi ekonomi yang sebenarnya,baik mikro maupun makro

h.pada pasar yang bergejolak namun pasti. 
B. Spekulan

a.Terkadang tidak rasional dalam mengambil keputusan

b. Melakukan analisis dengan cermat walaupun kadang-kadang manjpulatif.

c. Memanfaatkan informasi yang simpang siur dan membuat rumor yang menguntungkan dirinya.

d. Mengharapkan pengembalian yang relatif pendek

e. Memanfaatkan kondisi resiko tinggi dalam berspekulasi

f. Mengharapkan pengembalian yang tinggi dan menolak pengembalian yang rendah

g. Tidak peduli dengan kondisi perekonomian baik mikro maupun makro dan lebih suka bereaksi pada kondisi ekonomi yang bergejolak

h. Berdampak pada pasar yang bergejolak dengan fluktuasi yang tinggi.

\section{Kesimpulan}

Pasar modal(capitalmarket) merupakan bagian dari institusi-institusi keuangan (financialInstitutions).6 Hugh T. Patrick \& U Tun Wai menyebutkan 3 (tiga) definisi pasar modal; Pertama, dalam arti luas, pasar modal adalah keseluruhan sistem keuangan yang terorganisir, Termasuk bank-bank komersil dan semua perantara di bidang keuangan, surat berharga/klaim Jangka pendek panjang primer yang tidak langsung.

Keberadan pasar modal syariah sangat bermanfaat dalam perekonomian untuk mendorong praktisi usaha umat Islam dalam pasar modal yang sesuai dengan syariah. Perkembangan ekonomi suatu negara juga tidak mungkin lepas dari perkembangan pasar modal. Selain itu, umat Islam memerlukan pasar modal yang aktivitasnya sejalan dengan prinsip syariah.Pasar modal syariah berbeda dengan pasar modal konvensional. Saham yang diperdagangkan pada pasar modal syariah berasal dari emiten yang memenuhi kriteriakriteria syariah. Obligasi yang diterbitkan pun harus menggunakan prinsip syariah, seperti mudharabah, musyarakah, ijarah, istishna', salam, dan murabahah. Selain saham dan obligasi syariah, yang diperjual belikan pada pasar modal syariah adalah reksa dana syariah yang merupakan sarana investasi campuran yang menggabungkan saham dan obligasi syariah dalam satu produk yang dikelola oleh manajer investasi. 


\section{DAFTAR PUSTAKA}

Ali, F. (2016). Pasar Modal Syariah. Otoritas Jasa Keuangan, 1-10.

Faozan, A. (2013). Konsep Pasar Modal Syariah. Muqtasid: Jurnal Ekonomi Dan Perbankan Syariah, 4(2), 287. https://doi.org/10.18326/muqtasid.v4i2.287-310

Fauziah, A., Purwanto, B., \& Ermawati, W. J. (2020). Myopic Loss Aversion dan Literasi Keuangan Pada Pengambilan Keputusan Investor Pemula Indonesia. Jurnal Manajemen Dan Organisasi, 11(1), 1-7. https://doi.org/10.29244/jmo.v11i1.30498

Muhammad Yafidz. (n.d.). Saham : Pengertian dan Jenis. 2.

Wiyanti, D. (2013). Perspektif Hukum Islam Terhadap Pasar Modal Syariah Sebagai Alternatif Investasi Bagi Investor. Jurnal Hukum Ius Quia Iustum, 20(2), 234-254. https://doi.org/10.20885/iustum.vol20.iss2.art4

Zahroh, A. (2015). Instrumen Pasar Modal. Iqtishoduna Jurnal Ekonomi Islam, 5(1), 51-65. http://ejournal.iaisyarifuddin.ac.id/index.php/iqtishoduna/article/view/25

)1369. (', مكردجيان. No Title22-1. 